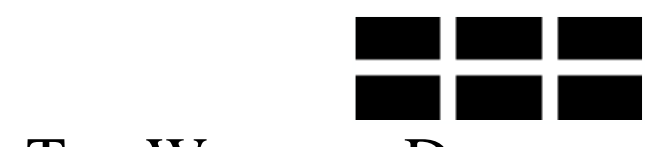

THE W ILLIAM DAVIDSON INSTITUTE

AT THE UNIVERSITY OF MICHIGAN BUSINESS SCHOOL

\title{
Duration and Risk of Unemployment in Argentina
}

By: Sebastian Galiani and Hugo A. Hopenhayn

William Davidson Working Paper Number 476

October 2001 


\title{
Duration and risk of unemployment in Argentina
}

\author{
Sebastian Galiani \\ Universidad de San Andres \\ and \\ Hugo A. Hopenhayn \\ University of Rochester and Universidad Torcuato Di Tella
}

\begin{abstract}
After a decade of structural reforms, unemployment rates have tripled in Argentina. This paper is concerned with the measurement of unemployment risk and its distribution. We show the importance of considering re-incidence in the measurement of unemployment risk and develop a methodology to do that. Our estimates for Argentina show that, though the typical unemployment spell is short, once re-incidence is taken into account, unemployment risk is high, has risen substantially in the last decade and is shared very unequally in the labor force. This counters the established view that unemployment is a small risk, short-duration phenomenon, which arises when re-incidence is not considered.
\end{abstract}

Keywords: Developing labor markets, hazard functions, unemployment duration and unemployment risk.

JEL classification: J0 and J6.

October 5, 2001

We thank the comments of H. Ennis and seminar participants at the Latin American Meeting of the Econometric Society.

Corresponding Author: Hugo Hopenhayn, Universidad Torcuato Di Tella, Miñones 2159/77, Buenos Aires, Argentina, 1428. TE: 5411-4784-0080. FAX: 5411-4784-9807. 


\section{Introduction}

After a decade of structural reforms in Latin American economies, there are growing concerns about the social consequences of increased employment volatility and the incidence of unemployment. The sharp rise in unemployment rates in Argentina lends support to this concern. Moreover, there is a perception that unemployment risk is very unequally distributed and that certain groups share an excess burden of the adjustment. This paper is concerned with the measurement of unemployment risk and its distribution. It raises some critical issues concerning the definition of unemployment risk, deals with the corresponding methodological considerations and provides estimates for the Buenos Aires labor market.

A standard method to evaluate unemployment risk is to consider the incidence of unemployment and its duration. Even when incidence may be high, it is usually understood that if unemployment spells are short-lived, the social cost of a typical unemployment spell is low. This paper shows that this reasoning is misleading when the typical employment spell is also short-lived. In such case, a correct account of unemployment risk must take into consideration the re-incidence of unemployment spells. Our estimates for the Buenos Aires labor market show that, contrary to the view that unemployment spells are short, total expected duration, accounting for repeated spells, is indeed long.

In this paper, we study the conditional distribution of total unemployment time for a two-year period. Using panel data from household surveys for the Buenos Aires area ${ }^{1}$ for the period 1989-1998, we estimate a Markov process for transitions from employment to

\footnotetext{
${ }^{1}$ This market covers approximately half of the labor force of the country.
} 
unemployment (and vice versa) that allow for duration dependence. From these estimates we obtain a distribution for the number of incidences and total unemployment time that someone entering unemployment will experience in the following two years.

We find that the median worker entering unemployment in 1998 has a total of 3 unemployment spells in the following two years and a total cumulative duration of 6.3 months. A worker with college education experiences 2 unemployment spells and 40 percent less time out of work. In contrast, the median young worker with low schooling exhibits 6 spells of unemployment and a total cumulative duration of 9.2 months. Our estimates also show the importance of long-term unemployment: of all workers unemployed at a given point in time, 34 percent spent more than one year of unemployment during the past two years. This figure is much closer to the high numbers found in European economies. Finally, comparing the first and last period of our sample, the median number of spells over the two-year period increased 50 percent while median cumulative unemployment duration increased by 43 percent.

\section{Motivation}

As a point of reference, consider European labor markets, which have experienced high unemployment rates since the mid-seventies. A salient characteristic of the high unemployment era has been the high proportion of long-term unemployment. Certainly, this feature made the European unemployment performance particularly problematic: although there have been other periods of high unemployment rates, long-term unemployment seems to be a characteristic of the last decades. ${ }^{2}$

\footnotetext{
${ }^{2}$ That is, controlling for the unemployment rate, long spells of unemployment were less important before the mid-seventies than later (cf. Machin and Manning, 2000). Generous unemployment insurance has been
} 
Some developing countries (like Argentina) have also experienced episodes of high unemployment rates during the 90 s. The lack of well-developed social security systems in those countries may suggest that most unemployment episodes are of a short-run nature. Indeed, the evidence of high flows in and out of unemployment confirms this hypothesis (see section 3). The Argentine case is particularly striking; the monthly inflow rate to unemployment has been over 2 percent since the beginning of the nineties and grew to 4 percent by the middle of the decade (see section 3 ). ${ }^{3}$ As it is well known, ceteris paribus, a high inflow rate implies low average unemployment duration. In steady state, the average duration of all episodes of unemployment equals the ratio of the unemployment rate to the inflow rate.

Table 1 presents average unemployment rates as well as short and long-term unemployment rates for OECD countries along with the Argentine figures for the period 1989-1998. This data show that the incidence of long-term unemployment in Argentina is substantially lower than in most European countries and it is similar to that of the US. Notice that, for example, the incidence of long-term unemployment for the OECD countries with an average unemployment rate over 10 percent is 45 percent, three times the Argentine incidence rate. Thus, by looking at these statistics, Argentina seems to be a country where unemployment is mostly a short-term phenomenon. ${ }^{4}$

blamed for this long duration. There is ample evidence suggesting that both the levels of unemployment benefits and the entitlement duration increase the duration of individual unemployment spells (cf. e.g. Narendranathan et al., 1985; Katz and Meyer, 1990; Meyer, 1990 and Carling et al., 1996).

${ }^{3}$ Most Latin American countries seem to have high inflow rates to unemployment in comparison to developed countries. For example, the average inflow rate to unemployment in Uruguay during the nineties has been 2 percent while the average steady state unemployment duration of all completed spells is 6 months.

${ }^{4}$ Indeed, the statistics reported in Table 1 refer to the length of the episodes of unemployment in progress. However, due to the extremely high inflow rates observed in Argentina, the average length of all spells is lower than the average length of the episodes in progress (see section 3). Akerlof and Main (1980) present a good discussion of the differences between these two statistics. 
Table 1: Unemployment rates in OECD and Argentina (\%) 1989-1998

\begin{tabular}{|c|cccc|}
\hline Country & $\begin{array}{c}\text { Total } \\
\text { unemployment } \\
\text { rates }\end{array}$ & $\begin{array}{c}\text { Short-tern } \\
\text { unemployment } \\
\text { rates }\end{array}$ & $\begin{array}{c}\text { Long-term } \\
\text { unemployment } \\
\text { rates }\end{array}$ & $\begin{array}{c}\text { Long-term } \\
\text { unemployment } \\
\text { incidence rates }\end{array}$ \\
\hline Spain & 19.8 & 9.3 & 10.5 & 53.2 \\
Ireland & 13 & 4.9 & 8.1 & 62.1 \\
Finland & 11.7 & 8.9 & 2.8 & 23.9 \\
France & 11.1 & 6.7 & 4.3 & 39.3 \\
Italy & 9.7 & 3.4 & 6.3 & 65.1 \\
Germany & 9.1 & 4.6 & 4.5 & 49.8 \\
Denmark & 9 & 6.5 & 2.5 & 27.7 \\
Belgium & 8.6 & 3.2 & 5.4 & 62.4 \\
United Kingdom & 8.4 & 5.1 & 3.2 & 38.6 \\
Netherlands & 6.4 & 3.3 & 3.2 & 49.5 \\
Sweden & 6.3 & 3.9 & 1.4 & 21.9 \\
Portugal & 5.6 & 4 & 2.6 & 45.4 \\
Norway & 5 & 2.1 & 1 & 25 \\
Switzerland & 2.8 & 2.3 & 0.7 & 18.8 \\
Japan & 2.8 & 6.1 & 0.5 & 30.3 \\
Australia & 8.8 & 6 & 2.7 & 24.3 \\
New Zealand & 8.0 & 8.5 & 1.9 & 10.6 \\
Canada & 9.6 & 4.9 & 1 & 16 \\
US & 5.8 & 9.8 & 0.9 & \\
Argentina & 11.6 & & 1.8 & \\
\hline
\end{tabular}

Notes: These rates are OECD standardized rates with the exception of Denmark and Italy. The data for Argentina refer to the Metropolitan region and follows the ILO definition. Hence, these rates are very similar. Long-term rates refer to those unemployed with duration over 1 year.

a) Period 1995-1998.

Sources: Authors elaboration based on Nickell and Layard (2000), OECD Employment Outlook (1999) and the Argentine Household Survey (GBA).

In this paper, we are concerned with the distribution of unemployment risk among different groups of individuals. The type of problem we are concerned with can be illustrated by the following example: consider the following two situations, both of which result in a 10 percent unemployment rate. In the first case, a given 10 percent of the labor force is unemployed the whole year; in the second, everyone is unemployed once a year for one-tenth of the year. Clearly, the distribution of unemployment differs substantially between the two cases. In the first scenario, the risk of unemployment is completely concentrated among a (relatively) small group of the population, while in the latter it is 
uniformly distributed among all individuals. Specifically, we deal with the following question: what groups are at risk of being unemployed high proportions of a given period of time?

One could conclude that in countries with high long-term incidence rates, the risk of unemployment is highly concentrated among small groups of workers, while in countries with high turnover and low long-term incidence rates, unemployment risk is more evenly distributed among the population. This paper argues that such a simple characterization of the labor market behavior could be misleading, at least for Argentina, and most likely also for other countries with high turnover rates. We show that even in a country where the inflow rate to unemployment is over 2 percent, the risk of unemployment is relatively concentrated in the population.

As mentioned above, the key in reconciling high inflow rates and concentrated unemployment is the fact that individuals often re-enter unemployment soon after leaving it. It is well known that the individuals with a past record of unemployment are most likely to be currently unemployed, a phenomenon that Heckman and Borjas (1980) have labeled occurrence dependence. Thus, due to multiple spells, unemployment affects some groups repeatedly, which tends to concentrate the risk of becoming unemployed.

In this regard, several authors (cf. e.g. Clark and Summers, 1979; Johnson and Layard, 1986 and Machin and Manning, 2000) have argued that the distribution of individuals unemployed at a point in time should be analyzed according to the amount of time those individuals will be unemployed in a certain period of time and not according to the duration of the current spell. Clark and Summers (1979), for example, estimate that 
in United States, the average person unemployed at a point in time during the period 1965-68 spent one-quarter of those 4 years unemployed.

Thus, especially in countries with high turnover, where the average duration of unemployment is low, a good indicator of long-term unemployment is the proportion of time an individual has been unemployed over a certain period of time.

\section{The facts}

The period we consider is marked by a sizable increase in unemployment. The unemployment rate rose from nearly 6 percent at the end of the eighties to around 15 percent towards the end of the nineties (see Figure 1, panel a).

All major groups in the labor force increased their unemployment rate. The change was the sharpest among high-age individuals, especially females. Although the female participation rate grew since the mid-eighties, that growth accelerated during the nineties (the largest proportional increase in the female participation rates occurred among the oldest groups). However, using transition matrix analysis, we estimate that for the population as a whole, the higher labor force participation rate numerically explains only a third of the increase in unemployment. Instead, the predominant factor in explaining the increase in unemployment during the nineties is the rise in the job destruction rate. This result is consistent with the rising trend in the inflow rate to unemployment observed during the nineties (see Figure 1, panel b). ${ }^{5,6}$

\footnotetext{
${ }^{5}$ The number of unemployed for less than one month is used as a proxy for inflows. This is a useful measure but it does underestimate somewhat the number of inflows, because persons who became unemployed but find a job in less than a month may not be included.

${ }^{6}$ For simplicity, we compute the inflow rate to unemployment as the ratio of the monthly inflow to the labor force instead to employment. This convention facilitates steady state computations.
} 
Figure 1: Unemployment in Argentina during the 90s
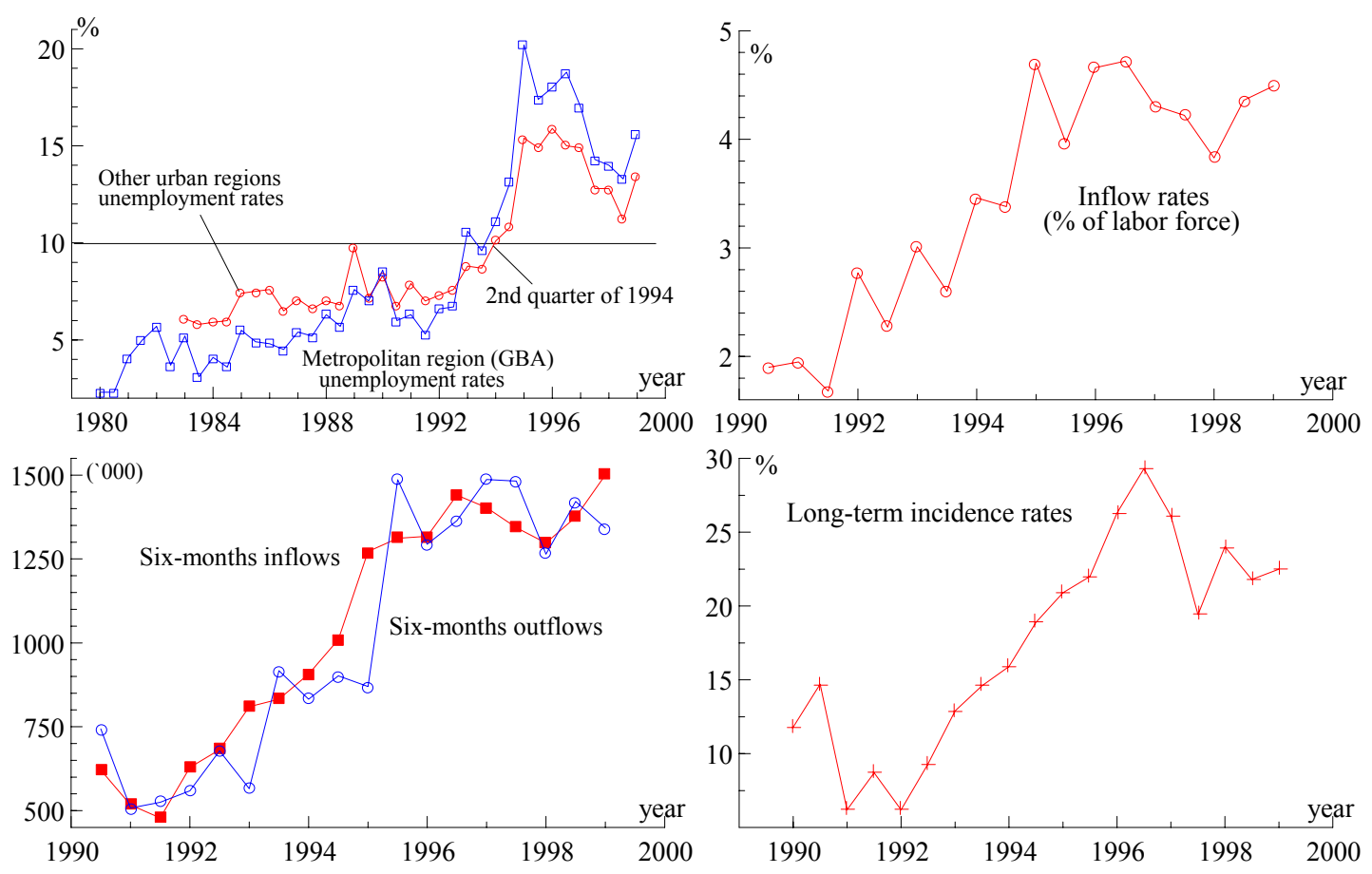

Notes: Panel b: The monthly inflow to unemployment is the number of people who, at a point in time, have been unemployed for one month or less. The inflow rate is the monthly inflow to unemployment divided by the total labor force at a point in time. Panel c: The six month inflow to unemployment is calculated as follows: $I(t, t-5)=(1 / 6) \sum_{j=1}^{6}\{(6-j) I(t-6)+j I(t)\}$, where $I(t)$ measures the monthly inflow to unemployment in period $t$. The six month outflow from unemployment is calculated as follows: $\mathrm{O}(\mathrm{t}, \mathrm{t}-5)=$ $\mathrm{U}(\mathrm{t}-6)+\mathrm{I}(\mathrm{t}, \mathrm{t}-5)-\mathrm{U}(\mathrm{t})$; where $\mathrm{U}(\mathrm{t})$ is the number of unemployed people in period t. Panel d: the long-term unemployed are those individuals whose current spell is a year or higher. The long-term incidence rate is the proportion of long-term unemployed people in total unemployment at a point in time.

Sources: Panel a: INDEC press reports. Panels b, $c$ and d: Authors elaboration based on the GBA Household Survey.

Figure 1 also illustrates an interesting feature of unemployment in Argentina. Contrary to the European experience, where the secular increase in unemployment can be arithmetically accounted for by a rising in the average duration (a fall in the outflow rate from unemployment), rather than a rise in the inflow rate, in Argentina both the inflow rate and the long-term incidence rate have increased over the nineties (see Figure 1, 
panels $b$ and $d$ ). Nevertheless, the long-term unemployment incidence rates are well below the numbers observed for most countries in continental Europe.

Likewise, the average duration of the current spells of unemployment has also increased during the nineties even though it has remained well below a year. Nevertheless, as we have seen, even if the duration of unemployment has increased, the incidence rate is still low compared to that in Europe. However, it is likely that we observe multiple unemployment spells among those individuals who experience unemployment. This may be inferred from the extremely high number of inflows episodes accumulated in a six-month period (see Figure 1, panel c). In this regard, without re-entry to unemployment, in the course of three years, the whole labor force would have entered unemployment once, implying the lower possible concentration of unemployment risk among the population. However, the incidence of unemployment has been probably much more concentrated in the population due to the existence of multiple spells. We explore this phenomenon in detail in the next section, by estimating the conditional distribution of the length of time an individual is unemployed over a two-year interval.

Table 2: Unemployment duration and flows

\begin{tabular}{|c|cccc|}
\hline Year & $\begin{array}{c}\text { Unemployment } \\
\text { rate } \\
(\%)\end{array}$ & $\begin{array}{c}\text { Inflow per month } \\
(\%)\end{array}$ & $\begin{array}{c}\text { Steady state } \\
\text { average completed } \\
\text { duration of all } \\
\text { spells (months }\end{array}$ & $\begin{array}{c}\text { Average } \\
\text { uncompleted } \\
\text { duration of current } \\
\text { spells (months) }\end{array}$ \\
\hline 1990 & 8.6 & 2.8 & 3.1 & 4.4 \\
1991 & 6.3 & 2.0 & 3.1 & 3.5 \\
1992 & 6.7 & 2.8 & 2.4 & 3.0 \\
1993 & 10.6 & 3.0 & 3.5 & 4.7 \\
1994 & 11.1 & 3.5 & 3.2 & 6.3 \\
1995 & 20.2 & 4.7 & 4.3 & 6.9 \\
1996 & 18.0 & 4.7 & 3.8 & 7.5 \\
1997 & 17.1 & 4.3 & 4.0 & 7.2 \\
1998 & 14.2 & 3.8 & 3.7 & 6.6 \\
1999 & 15.7 & 4.5 & 3.5 & \\
\hline
\end{tabular}

Source: Authors calculations based on GBA Household Survey, May. 


\section{Modeling unemployment risk}

In this section, we model the cumulative risk of unemployment. At any point in time, a worker could be in any of two states: Employed or Unemployed. ${ }^{7}$ A Markov process discussed in detail below determines the transition between these two states. This Markov process allows for duration dependence, i.e. the probability of transition from one state to the other varies with the time spent in the state of origin. The process depends on a set of covariates that capture individual characteristics. Consider a worker that enters unemployment. The process described above determines a distribution for the total time spent in the unemployment state in all spells (including the starting one) over the following two years. We focus on this measure of unemployment risk.

To study the conditional distribution of this random variable we estimate the transition probabilities (hazard rates) between employment and unemployment by estimating discrete time proportional hazard models. We adopt this modeling strategy because our data is collected at discrete dates as an ordinary longitudinal survey. To identify and efficiently estimate the parameters of our model, we exploit both the point sample information on the states of the stochastic process studied and backward recurrence time data on employment tenure and unemployment duration (see Magnac and Robin, 1994). The next subsection details the statistical model estimated.

\subsection{Estimating the hazard functions}

Generally, the duration of unemployment (employment) is studied by specifying the conditional probability of leaving unemployment (employment). Such hazard function 
models have been extensively used in the economic literature over the last two decades (cf. e.g. Lancaster, 1990 and Heckman and Singer, 1984).

Suppose there are individuals $i=1, \ldots, n$, who each enter unemployment (employment) at time $\mathrm{t}=0$. The instantaneous hazard rate function for person $i$ at time $\mathrm{t}>$ 0 is usually assumed to take a proportional form (see Cox, 1972). We model the baseline hazard function as a piecewise function, which is assumed constant within duration intervals and varying between them. This feature of the baseline hazard function allows us to introduce duration dependence in the state in a tractable way.

Consider a grid of duration periods $\left\{0=\mathrm{t}_{0}<\mathrm{t}_{1}<\ldots<\mathrm{t}_{\mathrm{J}}\right\}$, and for $j=1, \ldots, J$ let $\Delta_{\mathrm{j}}=\mathrm{t}_{\mathrm{j}}-$ $t_{\mathrm{j}-1}$ denote the length of each of the $J$ intervals. Thus, the baseline hazard rate is constant within each of these duration intervals.

Let $J(\mathrm{t})=\max \left\{j \mid \mathrm{t}_{\mathrm{j}}<\mathrm{t}\right\}$, so that $\mathrm{t}_{\mathrm{J}(\mathrm{t})} \leq \mathrm{t}<\mathrm{t}_{\mathrm{J}(\mathrm{t})+1}$. Given a vector of time-invariant covariates $\mathbf{x}=\left(\mathbf{x}_{1}, \mathbf{x}_{2}\right)$ and parameters $\beta=\left(\beta_{0},\left\{\beta_{\mathrm{j}}\right\}_{\mathrm{j}=1, \ldots, J}\right)$, the hazard rates are given by

$$
\mathrm{h}(\mathrm{t} ; \mathbf{x}, \beta)=\mathrm{g}\left(\mathbf{x}_{1}, \beta_{0}\right) \mathrm{h}_{\mathrm{J}(\mathrm{t})}\left(\mathbf{x}_{2}, \beta_{\mathrm{J}(\mathrm{t})}\right)
$$

where the specification adopted for the hazard functions have the usual log-linear form

$$
\mathrm{h}(\mathrm{t} ; \mathbf{x}, \beta)=\exp \left(\beta_{0}^{\prime} \mathbf{x}_{1}\right) \exp \left(\beta_{\mathrm{J}(\mathrm{t})}{ }^{\prime} \mathbf{x}_{2}\right)
$$

Given the above specification for the hazard rates, the (discrete-time) survival function has exactly the following form:

\footnotetext{
${ }^{7}$ We do not model transitions in and out of the labor force.
} 


$$
\mathrm{S}(\mathrm{t}, \mathbf{x}, \beta)=\exp \left(-\mathrm{g}\left(\mathbf{x}_{1} \beta_{o}\right)\left[\sum_{1 \leq \mathrm{j} \leq \mathrm{J}(\mathrm{t})-1} \mathrm{~h}_{\mathrm{j}}\left(\mathbf{x}_{2}, \beta_{\mathrm{j}}\right) \Delta_{\mathrm{j}}+\mathrm{h}_{\mathrm{J}(\mathrm{t})}\left(\mathbf{x}_{2}, \beta_{\mathrm{J}(\mathrm{t})}\right)\left(\mathrm{t}-\mathrm{t}_{\mathrm{J}(\mathrm{t})}\right)\right]\right)
$$

Our data consists of spells that may have been completed or continued between two consecutive survey interviews. At the time of the first interview, for both employment and unemployment spells, we have information on elapsed duration, which we denote by $\mathrm{t}_{0}$ months. In case of continuing (incomplete) spells, elapsed duration at the time of the second interview is given by $\mathrm{t}_{1}=\mathrm{t}_{0}+6$, since the survey takes place every six months. As usual, these observations can be treated as right-censored observations. In case of completed spells, the information on the duration of the spell is limited due to interval censoring. Letting $\delta$ denote the duration of the current spell, where $\delta \geq 0$, all we know is that $\mathrm{t}_{1} \in\left[\mathrm{t}_{\mathrm{o}}, \mathrm{t}_{\mathrm{o}}+6-\delta\right]$. That is, an upper bound for the duration of the job that ended between survey periods is given by $t_{\mathrm{o}}+6-\delta$, which would be exact if only one transition has taken place. The sample variability of $\delta$ identifies the hazard rates.

The conditional probability of a continuing spell, (ignoring the dependence on $\mathbf{x}$ and $\beta)$ is given by $\mathrm{S}\left(\mathrm{t}_{\mathrm{o}}+6\right) / \mathrm{S}\left(\mathrm{t}_{\mathrm{o}}\right)$ and the conditional probability of a completed spell is given by $\left[S\left(t_{0}\right)-S\left(t_{o}+6-\delta\right)\right] / S\left(t_{o}\right)$. Letting $I_{o}$ denote the set of individuals with continuing spells and $I_{1}$ those individuals with completed spells, the log-likelihood function is given by:

$$
\begin{aligned}
& \ln \mathrm{L}(\beta ; \mathbf{x})=\sum_{\mathrm{i} \in \mathrm{I}_{\mathrm{o}}}\left[\ln \mathrm{S}\left(\mathrm{t}_{\mathrm{i}}+6 ; \mathbf{x}_{\mathrm{i}}, \beta\right)-\ln \mathrm{S}\left(\mathrm{t}_{\mathrm{i}} ; \mathbf{x}_{\mathrm{i}}, \beta\right)\right]+ \\
& \quad \sum_{\mathrm{i} \in \mathrm{I}_{1}}\left[\ln \left\{\mathrm{S}\left(\mathrm{t}_{\mathrm{i}} ; \mathbf{x}_{\mathrm{i}}, \beta\right)-\mathrm{S}\left(\mathrm{t}_{\mathrm{i}}+6-\delta ; \mathbf{x}_{\mathrm{i}}, \beta\right)\right\}-\ln \mathrm{S}\left(\mathrm{t}_{i} ; \mathbf{x}_{\mathrm{i}}, \beta\right)\right]
\end{aligned}
$$


Finally, note that by restricting our estimates to conditional probabilities, we circumvent the problems associated to length bias sampling and non-stationarity of flows. This is also the reason why we do not include in our estimates the information of the elapsed length of the second spell for those individuals that completed the initial spell and were in the labor force at the time of the second interview. Finally, the use of the tenure information on states allows us to tackle the problem of interval censoring.

\subsection{Hazard rate estimates}

Our sample is drawn from the household survey for Greater Buenos Aires. The survey is a rotating panel in which 25 percent of the sample is replaced during each wave of the survey. Our sample consists of the matched rotating panels from May 1989 to October 1998. There are a total of approximately 64.000 individuals in the sample, evenly distributed throughout the sample period, of which over 44.000 have multiple observations. We further restrict the sample to those individuals with ages between 21 and 65 years old. Additionally, the estimate of the hazard rate from employment is made conditional on those individuals who are employed with a salary and are still in the labor force the following period. ${ }^{8}$

The proportional hazard function from unemployment is a function of a set of personal characteristics and fixed period effects while the piecewise baseline hazard function is a function of a set of dummy variables measuring duration dependence periods. ${ }^{9}$

\footnotetext{
${ }^{8}$ Therefore, we exclude from the sample self-employed, owner-managers and unpaid workers

${ }^{9}$ It is worth noting that in Argentina, the proportion of insured unemployed is extremely low (cf. Galiani and Nickell, 1999).
} 
The proportional hazard function from employment is a function of a set of personal characteristics. The piecewise baseline hazard function also varies by duration segment. The link function of these baseline hazards is modeled as a linear function of a dummy variable indicating the period 1995-1998 and a constant term. The differential effect on employment stability postulated for the period 1995-1998 is due to the changes in the labor market legislation of 1995. This reform introduced a trial period for all employment contracts and a wide set of fix-term contracts. There is evidence that this type of reforms increase employment volatility. Cabrales and Hopenhayn (1997) present evidence for Spain that shows a significant increase in the hazard rate from employment after the rules for temporary employment were substantially relaxed. Additionally, there are wellestablished theoretical arguments that show that lower job matches termination costs implies higher turnover rates (cf. e.g. Bertola and Rogerson, 1997 and Hopenhayn and Rogerson, 1993).

Since our objective is to model the conditional distribution of the length of time an individual is unemployed over a two-year interval, we model the hazard functions from both employment and unemployment as functions of individual characteristics exclusively; that is, we do not condition them on variables that measure the characteristics of the jobs or the job matches of the employed individuals (e.g., firm size). Otherwise, we should also need estimates of the conditional probabilities of transiting from one type of job or unemployment to every existing type of job.

In our empirical models, the age of the individual, the sex (a dummy that equals one if the individual is male), and the level of education, capture the individual characteristics. The schooling information is categorical. There is a set of dummy 
variables that measure the maximum level of the educational system attended by an individual and whether or not it has been completed. The educational categories are incomplete primary school, primary school, high school dropouts, high school, incomplete tertiary degree and tertiary degree (Schooling i, i = 1,..,6). The base category in the likelihood functions is the incomplete primary school (Schooling 1).

Tables 3 and 4 respectively present the estimate of the probability of leaving unemployment and the estimate of the probability of leaving employment. For each model, we report the coefficients, their standard errors, the probability value and the risk ratio. Naturally, the latter statistic is only reported for dummy variables.

Table 3: Modeling the probability of leaving unemployment

\begin{tabular}{|c|c|c|c|}
\hline Variable & Coefficient & P-value & Risk ratio \\
\hline Age & $\begin{array}{c}-0.0154 * * * \\
(0.0022)\end{array}$ & 0.0001 & \\
\hline Sex & $\begin{array}{c}0.5232 * * * \\
(0.0536)\end{array}$ & 0.0001 & 1.687 \\
\hline Schooling 2 & $\begin{array}{c}-0.1416 * * \\
(0.0835)\end{array}$ & 0.0450 & 0.868 \\
\hline Schooling 3 & $\begin{array}{c}-0.4348 * * * \\
(0.0912)\end{array}$ & 0.0001 & 0.647 \\
\hline Schooling 4 & $\begin{array}{c}-0.3294 * * * \\
(0.0980)\end{array}$ & 0.0004 & 0.719 \\
\hline Schooling 5 & $\begin{array}{c}-0.4023 * * * \\
(0.1112)\end{array}$ & 0.0001 & 0.669 \\
\hline Schooling 6 & $\begin{array}{c}-0.2990 * * * \\
(0.1285)\end{array}$ & 0.0100 & 0.742 \\
\hline $0-3$ months & $\begin{array}{c}0.1053 \\
(0.1773)\end{array}$ & 0.2763 & \\
\hline $3-6$ months & $\begin{array}{c}-0.4654 * * * \\
(0.1788)\end{array}$ & 0.0046 & \\
\hline $6-12$ months & $\begin{array}{c}-1.9962 * * * \\
(0.1838)\end{array}$ & 0.0001 & \\
\hline $12-24$ months & $\begin{array}{c}-1.9444 * * * \\
(0.1890)\end{array}$ & 0.0001 & \\
\hline Period fixed effects & Yes & & \\
\hline Mean log-likelihood & -0.695 & & \\
\hline Number of cases & 3073 & & \\
\hline
\end{tabular}

Notes: $* * *$ if the variable is statistically significant at the 1 percent level. $* *$ if the variable is statistically significant at the 5 percent level. 
Table 4: Modeling the probability of leaving employment

\begin{tabular}{|c|c|c|c|}
\hline Variable & Coefficient & P-value & Risk ratio \\
\hline Age & $\begin{array}{c}-0.0168 * * * \\
(0.002)\end{array}$ & 0.0001 & \\
\hline Sex & $\begin{array}{c}0.2567 * * * \\
(0.0468)\end{array}$ & 0.0001 & 1.292 \\
\hline Schooling 2 & $\begin{array}{c}-0.2044 * * * \\
(0.0724)\end{array}$ & 0.0024 & 0.815 \\
\hline Schooling 3 & $\begin{array}{c}-0.2407 * * * \\
(0.0771)\end{array}$ & 0.0009 & 0.786 \\
\hline Schooling 4 & $\begin{array}{c}-0.4566 * * * \\
(0.0812)\end{array}$ & 0.0001 & 0.633 \\
\hline Schooling 5 & $\begin{array}{c}-0.6580 * * * \\
(0.0904)\end{array}$ & 0.0001 & 0.518 \\
\hline Schooling 6 & $\begin{array}{c}-0.8845 * * * \\
(0.0968)\end{array}$ & 0.0001 & 0.413 \\
\hline $0-3$ months & & & \\
\hline $\begin{array}{r}\text { Constant } \\
\text { D95-98 }\end{array}$ & $\begin{array}{c}-0.4616 * * * \\
(0.1312) \\
0.4279 * * * \\
(0.1034)\end{array}$ & $\begin{array}{l}0.0002 \\
0.0001\end{array}$ & 1.587 \\
\hline $\begin{array}{l}\text { 3-6 months } \\
\text { Constant }\end{array}$ & $\begin{array}{c}-1.1046 * * * \\
(0.1246)\end{array}$ & 0.0001 & \\
\hline D95-98 & $\begin{array}{c}0.2043 * * \\
(0.0973)\end{array}$ & 0.0179 & 1.224 \\
\hline $\begin{array}{l}\text { 6-12 months } \\
\text { Constant }\end{array}$ & $\begin{array}{c}-3.2042 * * * \\
(0.1344)\end{array}$ & 0.0001 & \\
\hline D95-98 & $\begin{array}{c}0.3626 * * * \\
(0.1174)\end{array}$ & 0.0010 & 1.437 \\
\hline $\begin{array}{l}12-24 \text { months } \\
\text { Constant }\end{array}$ & $\begin{array}{c}-3.0747 * * * \\
(0.1193)\end{array}$ & 0.0001 & \\
\hline D95-98 & $\begin{array}{c}0.0879 \\
(0.0860)\end{array}$ & 0.1534 & 1.091 \\
\hline $\begin{array}{c}\text { More than } 24 \text { months } \\
\text { Constant }\end{array}$ & $\begin{array}{c}-3.7631 * * * \\
(0.1333)\end{array}$ & 0.0001 & \\
\hline D95-98 & $\begin{array}{c}0.2094 * * \\
(0.1024)\end{array}$ & 0.0204 & 1.233 \\
\hline $\begin{array}{l}\text { Mean log-likelihood } \\
\text { Number of cases }\end{array}$ & $\begin{array}{l}-0.397 \\
25328\end{array}$ & & \\
\hline
\end{tabular}

Notes: *** if the variable is statistically significant at the 1 percent level. ** if the variable is statistically significant at the 5 percent level. * if the variable is statistically significant at the 10 percent level.

In both cases, the demographic covariates are highly significant. The hazard rate from employment decreases monotonically in age and the level of education. For example, the hazard rate from employment decreases 12 percent with 10 additional years to the mean sample age and it is 58.7 percent lower for someone with a tertiary degree than for 
someone with incomplete primary school. ${ }^{10}$ The hazard rate from employment is 29.2 percent higher for males than for females (see the risk ratio in table 4).

Regarding the hazard rate from unemployment, the schooling effect is not monotone and it is somewhat ambiguous. It appears that it makes certain difference to finish primary school, but apart from that, there are little risk differences. The hazard rate from unemployment decreases 15 percent with 10 additional years to the mean sample age and it is considerable higher for males than for females (68.7 percent).

Both hazard rates present strong negative duration dependence. Thus, evidently, the probability of transiting between states is a function of the time spent in the state of origin. Lastly, the exit rate from employment increased substantially after more flexible contracts where introduced in 1995. For example, the hazard rate from employment of a worker in his or her first quarter of tenure increased 58.7 percent during the period 19951998.

Finally, in table 5 we present the mean survival rate both in employment and unemployment. The unemployment survival rates confirm that the unemployment duration of a spell is extremely low in Argentina. The employment survival rates are also extremely low and explain why we observe the remarkably high levels of turnover in the labor market documented in section 3. Clearly, an individual that is unemployed at least once in a period of two years is most likely to face multiple spells during that period.

10 The percentage change in a hazard rate as a result of a dichotomic variable is given by 100 [Exponential $(\alpha)-1]$, where $\alpha$ is the coefficient associated to the dummy variable. 
William Davidson Institute Working Paper 476

Table 5: Mean survival rates (\%): 1989-1998

\begin{tabular}{|c|c|c|}
\hline Duration & Employment & Unemployment \\
\hline 3 months & 52.0 & 21.9 \\
6 months & 32.6 & 10.3 \\
1 year & 28.8 & 7.6 \\
2 years & 22.5 & 4 \\
5 years & 15.2 & 0 \\
\hline
\end{tabular}

\subsection{Unemployment risk}

In this subsection, we consider the risk of unemployment for an individual that enters unemployment. The objective is to evaluate how this risk is distributed among the labor force. Although the risk associated to a single spell is low, the extremely low employment retention rates induce multiple spells that may spawn a high level of unemployment risk.

Table 6 presents some location moments of the distribution of the time an individual that enters unemployment will spend unemployed over two years. Additionally, in the last column of the table we add the median of the distribution of unemployment incidences (repeated spells) over two years. In the first row we present these moments for the average individual that enters unemployment in 1998. Over that period, the probability of staying out of work more than 6 months is higher than 0.5 . The expected mean time out of work is 7.3 months. If we compare this statistics with those corresponding to the average individual that entered unemployment in 1989, we observe that the entire distribution shifted to the right. The comparison of these two rows gives us a quantification of the increase in unemployment risk. For example, the median time an individual that enters unemployment will spend unemployed over two years has increased 43 percent. The expected median number of spells over two years increased 50 
percent. Actually, someone who enters unemployment expect to experience 3 spells of unemployment over a period of two years.

Table 6 also presents these statistics for several demographic groups. As can be seen, a worker with tertiary degree experiences 50 percent less number of unemployment spells and 40 percent less time out of work than an average unemployed. Females stay out of work longer even though they expect to experience fewer spells of unemployment. This is due to their lower hazard rate for exit from unemployment. Finally, the young unskilled face extremely high risk of unemployment: the median youth unskilled worker has 6 spells of unemployment and remains jobless 9.2 months out of two years.

Table 6: Unemployment risk:

Moments of the distribution of the time an individual that enters unemployment will spend unemployed over two years

\begin{tabular}{|c|c|c|c|c|c|}
\hline & \multicolumn{4}{|c|}{ Total time in two years } & \multirow[b]{2}{*}{$\begin{array}{c}\text { Number of } \\
\text { incidences } \\
\text { Median }\end{array}$} \\
\hline & First quartile & Median & Third quartile & Mean & \\
\hline $\begin{array}{c}\text { Average } \\
\text { individual } \\
\text { (1998) }\end{array}$ & 3.1 & 6.3 & 10.0 & 7.3 & 3 \\
\hline $\begin{array}{c}\text { Average } \\
\text { individual } \\
\text { (1989) }\end{array}$ & 2.3 & 4.4 & 7.6 & 5.8 & 2 \\
\hline $\begin{array}{c}\text { Average } \\
\text { incomplete } \\
\text { primary school } \\
(1998)\end{array}$ & 5.2 & 8.3 & 10.7 & 8.1 & 5 \\
\hline $\begin{array}{c}\text { Average } \\
\text { tertiary degree } \\
(1998)\end{array}$ & 2.0 & 3.8 & 7.0 & 5.4 & 2 \\
\hline $\begin{array}{c}\text { Average } \\
\text { incomplete } \\
\text { primary school } \\
18 \text { years old } \\
(1998)\end{array}$ & 7.0 & 9.2 & 10.9 & 8.8 & 6 \\
\hline $\begin{array}{c}\text { Average } \\
\text { females } \\
(1998)\end{array}$ & 2.9 & 6.6 & 12.5 & 8.7 & 2 \\
\hline
\end{tabular}


What is the importance of long-term unemployment? As indicated above, standard measures of long-term unemployment underestimate the importance of total incidence through multiple spells. Accordingly, a new definition is called for. We will say that an unemployed worker is long-term unemployed if he has been in that state for more than one year during the last two years.

We construct a theoretical sample of unemployed workers by performing a Monte Carlo simulation of the estimated model. All explanatory variables are set to their sample mean values except for the year dummy variable, which is set to 1998 . A total of 10,000 sample paths were generated of 264 periods (months) each. Our sample comprises all those paths that concluded in unemployment. For each path in this sample, we calculate the total time spent in unemployment during the last 24 periods. The mean value is 10.2 months and the median value is 8.6 months. Of all unemployed, 34 percent had been in that state for more than one year during the 2-years window: the long-term unemployed. This is more than twice the figure obtained without taking into account re-incidence and is close to the long-term unemployment figures for the OECD countries with average unemployment over 10 percent. Indeed, it is similar to the long-term incidence rate for France. Lastly, it is worth noting that this statistic is the appropriate one to contrast with any statistic computed for the episodes in progress at a point in time where long-term episodes are over represented. ${ }^{11}$

Thus, it seems reasonable to conclude that simple comparisons of long-term unemployment incidence rates, measured as the proportion of the current spells of

\footnotetext{
${ }^{11}$ In order to evaluate the accuracy of our model, we estimate the long-term incidence rate in our Monte Carlo sample; that is, we estimate the proportion of unemployed individuals whose current spell is a year or higher and we find that it is not significantly below the one obtained from the episodes in progress in May 1998. Thus, our model fits reasonable well the actual survey data on the duration of unemployment.
} 
episodes in progress with duration over a year, may be misleading in quantifying the risk of unemployment and its social costs. In particular, the perception that unemployment risk is very unequally distributed only in countries where the incidence of long-term unemployment is high is incorrect. We have shown that this type of reasoning is misleading when the typical employment spell is also short-lived. In such case, a correct account of unemployment risk must take into consideration the re-incidence of unemployment spells.

\section{Conclusions}

This paper is concerned with the measurement of unemployment risk and its distribution. Its main contribution is methodological. We have raised some critical issues concerning the definition of unemployment risk and have dealt with its methodological difficulties offering a solution.

We show that although the duration of a typical unemployment spell in Argentina is very short, the average individual that entered unemployment in 1998 had a probability higher than 0.5 of experiencing a total of 3 or more unemployment spells over two years and cumulative unemployment of over a third of this two-year period. Furthermore, the risk of unemployment has increased considerably throughout the decade: the median number of incidences increased 50 percent and the median cumulative duration rose 43 percent. This is explained mostly by a declining survival time in employment.

Our estimates also indicate that, accounting for re-incidence, the fraction of long-term unemployed is close to the high numbers encountered in European economies. Of all unemployment episodes in progress, 34 percent had been in that state for more than one 
year during a 2-years window. This is more than twice the figure obtained without taking into account re-incidence into unemployment. This counters the view that unemployment is a small risk, short-duration phenomenon, which arises when re-incidence is not considered. Thus, in Argentina, unemployment risk is high, has risen substantially in the last decade and is shared very unequally in the labor force.

More generally, there is the view that in countries with high long-term incidence rates, the risk of unemployment is highly concentrated among small groups of workers, while in countries with high turnover and low long-term incidence rates, unemployment risk is more evenly distributed among the population. This paper shows that such a simple characterization of the labor market behavior is not accurate, at least for Argentina, and most likely for other countries with high turnover rates like most Latin American countries. In this paper we have shown that even in a country where the inflow rate to unemployment is over 2 percent, the risk of unemployment is relatively concentrated in the population.

In conclusion, the contributions of the paper are of interest to measure unemployment risk and its distribution, specially, but not only, for developing countries where the typical unemployment spell is short-lived. 


\section{References}

Akerlof, G. and B. Main, 1980, "Unemployment spells and unemployment experience", American Economic Review, 70, 885-93.

Bertola, G. and R. Rogerson, 1997, "Institutions and labor reallocation", European Economic Review, 41, 1147-71.

Cabrales, A. and H. Hopenhayn, 1997, "Labor-market flexibility and aggregate employment volatility", Carnegie-Rochester Conference Series on Public Policy, 46, 189-228.

Carling, K; P.A. Edin and B. Holmlund, 1996, "Unemployment duration, unemployment benefits and labor market programs in Sweden", Journal of Public Economics, 59, 313-34.

Clark, K. and L. Summers, 1979, "Labor market dynamics and unemployment: a reconsideration", Brookings Papers on Economic Activity, 1, 13-72.

Cox, D., 1972, "Regression models and life-tables", Journal of the Royal Statistic Society, B, 30, 248-75.

Galiani, S. and S. Nickell, 1999, "Unemployment in Argentina in the 1990s", Instituto Torcuato Di Tella, Working Paper DTE 219.

Heckman, J. and G. Borjas, 1980, "Does unemployment cause future unemployment? Definitions, questions, and answers from a continuous time model of heterogeneity and state dependence", Economica, 47, 247-83.

Heckman, J. and B. Singer, 1984, "Econometric duration analysis", Journal of Econometrics, 24, 63-112.

Hopenhayn, H. and R. Rogerson, 1993, "Job turnover and policy evaluation: a general equilibrium analysis", Journal of Public Economics, 101, 915-38.

Johnson, G. and R. Layard, 1986, "Natural rate of unemployment", in Handbook of Labor Economics, Volume 2, Ashenfelter, O. and R. Layard (eds.), North-Holland.

Katz, L. and B. Meyer, 1990, "The impact of the potential duration of unemployment benefits on the duration of unemployment", Journal of Public Economics, 41, 45-72.

Lancaster, T. (1990): The Econometric Analysis of Transition Data, Econometric Society Monographs, Cambridge University Press.

Machin, S. and A. Manning, 2000, "Long-term unemployment in Europe", in Handbook of Labor Economics, Volume 3C, Ashenfelter, O. and D. Card (eds.), North-Holland.

Magnac, T. and J. Robin, 1994, "An econometric analysis of labour market transitions using discrete and tenure data", Labour Economics, 327-46.

Meyer, B., 1990, "Unemployment insurance and unemployment spells", Econometrica, 58, 75782.

Narendranathan, W; S. Nickell and J. Stern, 1985, "Unemployment benefits revisited", Economic Journal, 95, 307-29.

Nickell, S. and R. Layard, 2000, "Labor markets institutions and economic performance", in Handbook of Labor Economics, Volume 3C, Ashenfelter, O. and Card, D. (eds.), North-Holland. OECD (1999): OECD Employment Outlook, June 1999. 


\section{DAVIDSON INSTITUTE WORKING PAPER SERIES - Most Recent Papers}

The entire Working Paper Series may be downloaded free of charge at: www.wdi.bus.umich.edu

CURRENT AS 7/10/02

\begin{tabular}{|c|c|c|}
\hline Publication & Authors & Date \\
\hline No. 476: Duration and Risk of Unemployment in Argentina & $\begin{array}{l}\text { Sebastian Galiani and Hugo A. } \\
\text { Hopenhayn }\end{array}$ & Oct. 2001 \\
\hline $\begin{array}{l}\text { No. 475: After, Before and During: Returns to Education in the } \\
\text { Hungarian Transition }\end{array}$ & $\begin{array}{l}\text { Nauro F. Campos and Dean } \\
\text { Jolliffe }\end{array}$ & Apr. 2002 \\
\hline No. 474: The Locking-in Effect of Subsidized Jobs & Jan C. van Ours & June 2002 \\
\hline No. 473: How Reform Worked in China & Yingyi Qian & June 2002 \\
\hline No. 472: An Economic Perspective on Russia's Accession to the WTO & Robert M. Stern & June2002 \\
\hline $\begin{array}{l}\text { No. 471: The Effects of Ownership Forms and Concentration on Firm } \\
\text { Performance after Large-Scale Privatization }\end{array}$ & Evzen Kocenda and Jan Svejnar & May 2002 \\
\hline $\begin{array}{l}\text { No. 470: Growth in Transition: What We Know, What We Don't, and } \\
\text { What We Should }\end{array}$ & $\begin{array}{l}\text { Nauro F. Campos and Fabrizio } \\
\text { Coricelli }\end{array}$ & Feb. 2002 \\
\hline $\begin{array}{l}\text { No. 469: Barriers to Investment by Russian Firms: Property Protection } \\
\text { or Credit Constraints? }\end{array}$ & Susan J. Linz & May 2002 \\
\hline No. 468: Job Satisfaction Among Russian Workers & Susan J. Linz & May 2002 \\
\hline $\begin{array}{l}\text { No. 467: Assessing the Problem of Human Capital Mismatch in } \\
\text { Transition Economies }\end{array}$ & $\begin{array}{l}\text { Viliam Druska, Byeong ju Jeong, } \\
\text { Michal Kejak, and Viatcheslav } \\
\text { Vinogradov }\end{array}$ & Mar. 2002 \\
\hline $\begin{array}{l}\text { No. 466: Motivating Russian Workers: Analysis of Age and Gender } \\
\text { Differences }\end{array}$ & Susan J. Linz & Feb. 2002 \\
\hline No. 465: Virtual Reality: Barter and Restructuring in Russian Industry & Gary Krueger and Susan J. Linz & Apr. 2001 \\
\hline $\begin{array}{l}\text { No. 464: Lending of Last Resort, Moral Hazard and Twin Crises: } \\
\text { Lessons from the Bulgarian Financial Crisis 1996/1997 }\end{array}$ & $\begin{array}{l}\text { Michael Berlemann, Kalin } \\
\text { Hristov and Nikolay Nenovsky }\end{array}$ & May 2002 \\
\hline $\begin{array}{l}\text { No. 463: Deindustrialisation. Lessons from the Structural Outcomes of } \\
\text { Post-Communist Transition }\end{array}$ & $\begin{array}{l}\text { Tomasz Mickiewicz and Anna } \\
\text { Zalewska }\end{array}$ & Jan. 2002 \\
\hline $\begin{array}{l}\text { No. 462: Joint Liability Lending and the Rise and Fall of China's } \\
\text { Township and Village Enterprises }\end{array}$ & Albert Park and Minggao Shen & July 2001 \\
\hline $\begin{array}{l}\text { No. 461: A Refinancing Model of Decentralization with Empirical } \\
\text { Evidence from China }\end{array}$ & Albert Park and Min & Apr. 2002 \\
\hline $\begin{array}{l}\text { No. 460: The Effects of Market Liberalization on the Relative Earnings } \\
\text { of Chinese Women }\end{array}$ & $\begin{array}{l}\text { Margaret Maurer-Fazio and } \\
\text { James Hughes }\end{array}$ & Mar. 2002 \\
\hline $\begin{array}{l}\text { No. 459: The Role of Education in Determining Labor Market } \\
\text { Outcomes in Urban China's Transitional Labor Markets }\end{array}$ & Margaret Maurer-Fazio & Apr. 2002 \\
\hline $\begin{array}{l}\text { No. 458: Real and Monetary Convergence within the European Union } \\
\text { and Between the European Union and Candidate Countries: } \\
\text { A Rolling Cointegration Approach }\end{array}$ & $\begin{array}{l}\text { Josef C. Brada, Ali M. Kutan and } \\
\text { Su Zhou }\end{array}$ & Apr. 2002 \\
\hline No. 457: Credit Ratings as Coordination Mechanisms & $\begin{array}{l}\text { Arnoud W. A. Boot and Todd T. } \\
\text { Milbourn }\end{array}$ & Mar. 2002 \\
\hline $\begin{array}{l}\text { No. 456: Balkan and Mediterranean Candidates for European Union } \\
\text { Membership: The Convergence of their Monetary Policy with that of the } \\
\text { European Central Bank }\end{array}$ & Josef C. Brada and Ali M. Kutan & Apr. 2002 \\
\hline $\begin{array}{l}\text { No. 455: Russian Financial Transition: The Development of Institutions } \\
\text { and Markets for Growth }\end{array}$ & David M. Kemme & Oct. 2001 \\
\hline $\begin{array}{l}\text { No. 454: Does the Market Pay Off? Earnings Inequality and Returns to } \\
\text { Education in Urban China }\end{array}$ & Xiaogang $\mathrm{Wu}$ and $\mathrm{Yu} \mathrm{Xie}$ & Apr. 2002 \\
\hline $\begin{array}{l}\text { No. 453: Entrepreneurs' Access to Private Equity in China: } \\
\text { The Role of Social Capital }\end{array}$ & Bat Batjargal and Mannie M. Liu & Apr. 2002 \\
\hline $\begin{array}{l}\text { No. 452: The Determinants of Privatised Enterprise Performance in } \\
\text { Russia }\end{array}$ & $\begin{array}{l}\text { Alan A. Bevan, Saul Estrin, Boris } \\
\text { Kuznetsov, Mark E. Schaffer, } \\
\text { Manuela Angelucci, Julian } \\
\text { Fennema and Giovanni } \\
\text { Mangiarotti }\end{array}$ & June 2001 \\
\hline
\end{tabular}

